\title{
Relationship Between Economic Growth and the Banking and Insurance Trade Performance for Select Asian Countries - Panel Co-Integration Model
}

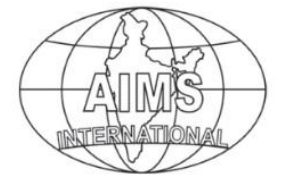

DOI: $10.26573 / 2017.11 .2 .3$

Volume 11, Number 2

May 2017, pp. 117-134

\author{
Srijanani Devarakonda \\ Vignana Jyothi Inst. of Management, India \\ (dr.srijanani@vjim.edu.in) \\ Usha Munipalle \\ Osmania University, India \\ (muni_21@rediffmail.com)
}

Literature suggests that financial institutions are the best indicators of a country's real development potential and significantly influence the economic development (Talliman et al. 1998; Goldsmith 19690. Patrick (1966) found that the most successful economies tend to be the ones that developed sophisticated financial systems at an early stage. Financial sector development (FSD) can play either a leading role in economic growth or it may take a more passive role (derived demand) in response to expanding economic needs. The paper empirically examines these relationships. Although there are studies which measure the impact of banking and insurance trade performance on the economic growth of economies, there is no study which investigates he impact of economic growth on the banking and insurance performance in low and middle income countries in South Asia. This paper examines the relationship between economic growth and banking and insurance performance in the select Asian countries using Panel Co-integration Method. This article's objective is to investigate the link between banking and insurance sector development and economic growth and hence to fill a gap in the current finance-growth nexus literature.

Keywords: Economic Growth, South Asian Countries, Banking and Insurance Performance, GDP Percapita, Panel Cointegration, Fixed Effects Model, Domestic Credit

\section{Introduction}

Empirical evidence and theoretical studies have shown that countries with betterdeveloped financial systems enjoy faster and more stable long-run growth. The need to stimulate and manage economic growth is a global topic of utmost importance in advanced, emerging, and less-developed countries. Patrick (1966) found that the most successful economies tend to be ones which at an early stage have developed sophisticated financial systems. Financial sector development (FSD) can play either a leading role in economic growth or it may take a more passive role (derived demand) in response to expanding economics needs.

The empirical literature on finance and growth is enormous. Since the seminal work of King and Levine (1993), many studies have tested the so-called financegrowth nexus. In a comprehensive overview article, Levine (1997) surveys not less than 280 studies. Although some authors argue that finance merely reacts to 
economic development, most of the empirical evidence reports a robust, positive, causal effect of finance on growth (e.g., Levine et al., 2000).

Among financial intermediaries, in performing functions of financial system insurance companies play important role. By issuing insurance policies they collect funds and transfer them to deficit economic units for financing real investment. Insurance sector could be one of the factors contributing to economic growth. Innovative insurance distribution channels like bancassurance and e-channel could lower the distribution costs and increase efficiency of transfer saving into investments. Thus, these developments in insurance sector could positively affect economic growth rate. Regarding regulation Roubini and Sala-i-Martin (1992) revealed that a government repression of a financial sector has negative effect on growth.

The continuing globalization of economic activity and the challenge of attracting productive investment in a competitive international environment necessitate the need to maintain a healthy and efficient financial sector.

The present study examines the dynamic relation between growth, domestic credit and money and quasi money to banking and insurance as a percentage of total trade in services for the select Asian countries which fall in the Low and Middle income groups using time-series data from 2005 to 2012. There is however no study which considers the financial deepening, GDP percapita and the domestic credit as a percentage of GDP and their impact on the increase or decrease in the Banking and Insurance performance in the total trade in services.

\section{Theoretical Background}

Both theoretical and empirical evidence suggest a strong financial sector promotes economic growth. Seven decades ago, Schumpeter (1934) stressed the role of the banking sector as a financier of productive investments and thus as an accelerator of economic growth. Most of the theoretical models relevant to our discussion, however, followed the emergence of endogenous growth theory. Pagano (1993) suggests three ways in which the development of financial sector might affect economic growth under the basic endogenous growth model. First, it can increase the productivity of investments. Second, an efficient financial sector reduces transaction costs and thus increases the share of savings channelled into productive investments. Third, financial sector development can either promote or decline savings. Greenwood and Jovanovic (1990), Levine (1991), Bencivenga and Smith (1991) and Saint-Paul (1992) have all constructed theoretical models wherein efficient financial markets improve the quality of investments and enhance economic growth. In the Greenwood and Jovanovic model (1990), the primary task of financial intermediaries is to channel funds to the most profitable investments they can identify by using information that they have gathered and analysed. The higher rate of return earned on capital promotes economic growth, which, in turn, provides the means to implement costly financial structures. An efficient financial sector also improves the liquidity of investments. In the models of Levine (1991) and Bencivenga and Smith (1991), financial markets improve firm efficiency by eliminating the premature liquidation of firm capital. During liquidity shocks, investors can sell their shares to another agent. Financial markets may also promote growth by increasing the proportion of resources allocated to firms. Through the diversification of productivity risk, even risk-averse investors can invest in firms. Under Saint-Paul's 
(1992) model, productivity growth is achieved through a broader division of labour and specialisation of enterprises. Specialisation, however, carries risk. Financial intermediaries support specialisation by permitting investors to hedge with a diversified portfolio. Specialisation in the absence of a properly functioning financial sector, however, may be too risky individual investor. If it is, financing for efficiency improving projects dries up. Blackburn and Hung (1996) identify a two-way causal relationship between growth and financial development. In their model, the lack of a financial sector means that every investor must individually monitor projects, so that the costs of monitoring are excessive. With a well-developed financial sector, monitoring tasks are delegated to intermediaries. Transaction costs are reduced and more savings can be allotted to investments that produce new technology. Ultimately, this promotes economic growth.

\section{Empirical Studies}

A number of studies empirically analyse the relationship between financial sector development and economic growth (Levine 1997, Thiel 2001, Wachtel 2001). Goldsmith's work (1969) provides the earliest evidence that development of financing accelerates economic growth. However, the measure (deposits to GDP) used for financial sector development was highly simplified and the direction of causality was never assessed.

King and Levine (1993) study cross-country data for 80 countries. They measured financial sector development with four indicators: the amount of liquid liabilities divided by GDP, the importance of commercial banks in relation to central bank when allocating credit, the ratio of credit allocated to private enterprises to total domestic credit, and credit to private sector divided by GDP. After controlling for other factors affecting economic growth, King and Levine find a strong positive relation between each of the financial development indicators and economic growth. Using crosscountry analysis, Levine and Zervos $(1996,1998)$ research the role of stock markets and the banking sector. They conclude that stock market liquidity and bank development robustly correlate with economic growth.

Rajan and Zingales (1998) strongly criticise some of the variables used for measuring financial sector development and conclusions about causality in these studies. They argue that growth of the financial sector and economic growth can be driven by a common variable such as the savings rate and that the amount of credit and size of the stock market may predict economic growth as forward-looking financial markets anticipate growth. Rajan and Zingales note enterprises reliant on external financing develop faster in countries with well-developed financial sectors. Their study supports the hypothesis that causality runs from financial development to economic growth. In the literature, studies using cross-sectional data tend to find a causal relationship from financial sector development to economic growth.

Cross-country regressions, however, are criticised for ignoring large differences between countries (Arestis \& Demetriades 1997, Neusser \& Kugler 1998), as well as the reliability of results due to the instability (Bank of Finland, Institute for Economies in Transition BOFIT Discussion Papers 14/2002, Quah 1993).

Some economists have expressed scepticism about the ability of cross-country regressions to explain the direction of causality. For example, Rousseau and Wachtel (2000) argue that often components, even pre-determined, measuring financial sector development, remain correlated with the contemporaneous measures. Thus, when 
banks anticipate higher economic growth, they may allocate more credit. In addition, GDP growth rates tend to be correlated serially. For these reasons, Rousseau and Wachtel argue, cross-country analyses fail to unambiguously determine the direction of causality.

Goldsmith (1969) was the first to show empirically the existence of a positive relationship between financial development and economic growth, and provides the earliest evidence that development of financing accelerates economic growth. He in his work showed that, the evolution of domestic financial markets leads to a high level of capital accumulation efficiency, and the positive correlation between financial development and growth is mainly due to the efficient use of capital stock.

Hicks (1969) also noticed that financial institutions might facilitate growth. In his study he focused on capital formation. Capital formation can be influenced by financial institutions through altering the savings rate or by reallocating savings among different capital producing technologies.

Adams, Andersson and Landermark in their study found that the development of insurance fosters demand for banking services but only in times of economic growth. For the entire period of the analysis, they found that banking has the predominant influence on both economic growth and the demand for insurance. McKinnon (1973) and Shaw (1973) demonstrate the importance of financial liberalisation in promoting savings and investment, and admit the significance of financial development in promoting economic growth through high capital productivity.

Greenwood and Jovanovic (1990) model the dynamic interactions between financial sector development and economic growth and tested the causality between them. They find that an expanded system of financial intermediation is able to allocate more capital to efficient investments and promote economic growth. King and Levine (1993), studied a sample of 70 countries, introduced new measures of financial development and examined the impact of financial development on economic growth, capital accumulation pace and economic factors. The results show an empirical link between financial development indicators and growth.

Demetriades and Hussein (1996) examined 16 countries and showed that finance is a leading sector in the process of economic development. They also find bidirectional causality between financial development and economic growth, mainly in developing countries. Odedokun (1996) in his study analysed 71 developing countries and showed that financial intermediation promote economic growth, in the majority of those countries. According to Hicks the industrial revolution in England was mainly caused by the capital market improvements that moderated liquidity risk. Accordingly, Levine and Zevros (1998) reach the conclusion that financial development is an accurate indicator of economic growth. Roussau and Watchell (2000) applied time series tests on the variables financial development and economic growth in 5 countries. Using measures of financial development which include banking and non-banking assets, they found that the most dominant causality direction is financial development towards economic growth. The VAR approach allows the identification of long-term effects of financial development on growth and considers the dynamic interactions between the explanatory variables.

Ward and Zurbruegg (2000) examined the relationship between GDP and insurance growth. With, the data set of 9-OECD countries, and these countries were Australia, Austria, Canada, France, Italy, Japan, Switzerland, UK and US. It was found that insurance premium was Granger Cause of GDP in some countries but for some 
countries it was not true. Koivu (2002) find that the efficiency of the banking sector accelerates economic growth in the transition economies. Drakos (2002) examined also the relation between financial sector and economic development in 21 transition economies and showed that imperfect competition in banking sectors lowers economic growth and deepen business cycles.

Calderon and Liu (2003) studied a large sample of 109 developing and industrial countries and found that: (1) financial development leads to economic growth in all countries; (2) financial deepening stimulates economic growth and, simultaneously, economic growth propels financial development; (3) financial deepening contributes more to the causal relationships in the developing countries than in the industrial countries, which implies that the developing countries have more room for financial and economic improvement; and (4) the longer the sampling interval, the larger the effect of financial development on economic growth, which suggests that it takes time for financial deepening to impact the real economy.

Muthusamy and Meera (2008) demonstrated the important role of Indian life insurance sector in economic development. Parekh and Banerjee (2010) reviewed that in India insurance sector has had significant impact on the economic development. This sector is gradually increasing and its contribution in GDP is also increasing.

Han et al. (2010) investigated the relationship between insurance development and economic growth, using the data set of 77 countries. It was found that insurance density impact plays very important role in developing countries rather than developed ones. Ching, et al. (2011) analyzed the existence of causal relationship between total assets of general insurance sector and GDP in Malaysia. It was found that the long-run relationship exists between the total assets of general insurance and GDP and in the short-run causal relationship was absent (in both directions).

Lee et al. (2013) analyzed the long term and short term relationship between the GDP and real life insurance premium of 41 countries. It was found that in the long term one unit increment in the real life premium will raise the GDP by 0.06 units. The life insurance markets development determines the economic growth in the long-run and in the short term, bidirectional causalities were found between them.

Chang et al. (2013) investigated the causal relationship between the insurance activities and GDP, using a data set of 10 OECD countries. It was found that there was a significant and positive relationship between the overall insurance growth and economic growth for 5 countries out of 10 OECD countries.

At the regional level, a few studies attempt to test the importance of bank efficiency via a more sophisticated measure. In line with the approach used in this paper, Lucchetti et al. (2001) measure the efficiency of Italian banks with stochastic cost-frontier analysis. The study's systematic deviations from optimal cost due to a poor allocation of input factors measure the resources wasted during the intermediation process. The results suggest that both the volume of originated credit as well as bank-specific efficiency scores are significantly and positively related to regional economic growth, respectively.

Recently, Koetter and Wedow (2006) and Hasan et al. (2009) provide some evidence along the same line for German agglomeration and European regions, respectively. These regional growth studies indicate that bank efficiency is likely to spur growth in an independent and economically significant way. 
Although there are studies which measure the impact of banking and insurance performance on the economic growth of economies, there is no study which studies the impact of economic growth on the banking and insurance performance in low and middle income countries in South Asia. The objective of the present study is to examine the relationship between economic growth on the performance of trade in banking and insurance services in select Asian countries (Indonesia, India, Sri Lanka, Maldives, Malaysia, Pakistan, Phillippines and Thailand). These are Low and Middle income countries and are also chosen based on the availability of data.

\section{Data Sources}

The information and data for the present study (is) are drawn mainly from standard and authentic secondary sources such as publication and reports of RBI, World Bank, IMF etc., to study the relationship between economic growth and banking and insurance performance panel co-integration method has been used. For studying the impact of economic growth on the banking and insurance trade performance, four variables have been identified. Gross domestic Product Per capita [GDPP], Financial deepening i.e., M2 to Gross Domestic Product [M2toGDP], Domestic Credit as percentage of Gross Domestic Product [DOMCREDIT] are taken are the dependent variables representing economic growth and Banking and insurance performance [BIPER] is taken as an independent variable to represent the banking and insurance trade performance.

Hypothesis (i) There is no co-integration evidence between BIPER and Dom Credit (ii) There is no co-integration evidence between BIPER and GDPP iii) There is no cointegration evidence between BIPER and M2 to GDP.

Where BIPER means Banking and insurance share as percentage of total services of country; GDPP is Gross domestic Product Per capita of country; M2GDP $=$ Ratio of M2 to Gross Domestic Product of country; DOMCREDIT = Domestic Credit as percentage of Gross Domestic Product of country.

To study which countries have strong relationship between Economic Growth and Banking and insurance performance, fixed effects - a panel regression model of econometrics has been applied.

\section{Domestic Credit to GDP}

Domestic Credit to GDP measures the degree of bank intermediation towards private sector. This is one of the widely used measures of financial intermediation. Domestic credit provided by the financial sector includes all credit to various sectors on a gross basis, with the exception of credit to the central government, which is net. The financial sector includes monetary authorities and deposit money banks, as well as other financial corporations where data are available (including corporations that do not accept transferable deposits but do incur such liabilities as time and savings deposits). Examples of other financial corporations are finance and leasing companies, money lenders, insurance corporations, pension funds, and foreign exchange companies ${ }^{1}$.

\footnotetext{
${ }^{1}$ The World bank, World Development Indicators
} 


\section{Domestic Credit Provided by Financial Sector}

The Domestic credit provided by banking sector (\% of GDP) varies by country. The country with the highest value in the world is Japan, with a value of 341.69. The country with the lowest value in the world is Libya, with a value of -65.93 .

The following Table shows the value of domestic trade and the rank of the countries. While Japan, Cyprus, United States, Ireland, United Kingdom, Netherlands, Hong Kong, Denmark and Portugal stand in the first ten ranks in the amount of Domestic credit provided by the financial sector (\% to GDP), the select eight countries only Malaysia and Thailand are in ranks below 30, India with 60 rank all the others range from 60 to 110th rank in the world ranking.

Table 1 World Ranking of the Domestic Credit Provided by Financial Sector (\% GDP) Ratio

\begin{tabular}{|c|l|c|c|}
\hline Rank & \multicolumn{1}{|c|}{ Country } & Value & Year \\
\hline 1 & Japan & 341.69 & 2011 \\
\hline 2 & Cyprus & $330 . e$ & 2011 \\
\hline 3 & United States & 232.51 & 2011 \\
\hline 4 & Spain & 230.91 & 2011 \\
\hline 5 & Ireland & 225.67 & 2011 \\
\hline 6 & United Kingdom & 212.62 & 2011 \\
\hline 7 & Netherlands & 211.37 & 2011 \\
\hline 8 & Hong Kong SAR, China & 207.06 & 2011 \\
\hline 9 & Denmark & 205.45 & 2011 \\
\hline 10 & Portugal & 204.10 & 2011 \\
\hline $\mathbf{6 0}$ & India & $\mathbf{7 4 . 1 2}$ & $\mathbf{2 0 1 1}$ \\
\hline 110 & Indonesia & 38.51 & 2011 \\
\hline 28 & Malaysia & 128.74 & 2011 \\
\hline 106 & Maldives & 39.53 & 2011 \\
\hline 86 & Philippines & 51.83 & 2011 \\
\hline 102 & Pakistan & 43.28 & 2011 \\
\hline 95 & Sri Lanka & 46.18 & 2011 \\
\hline 16 & Thailand & 159.21 & 2011 \\
\hline
\end{tabular}

Source: International Monetary Fund, International Financial Statistics and Data Files and World Bank and OECD GDP Estimates

GDPP (Per Capita GDP) is a measure of the total output of a country that takes the gross domestic product (GDP) and divides it by the number of people in the country. The per capita GDP is especially useful when comparing one country to another because it shows the relative performance of the countries.

\section{M2 to GDP (Money and Quasi Money Growth (\%))}

The financial intermediation is also measured by M2 to GDP, which is an indicator of the financial deepening and indicates the deposit mobilization role of the financial system. It measures the average annual growth rate in money and quasi money. Money and quasi money comprise the sum of currency outside banks, demand deposits other than those of the central government, and the time, savings, and 
foreign currency deposits of resident sectors other than the central government. This definition is frequently called M2. The change in the money supply is measured as the difference in end-of-year totals relative to the level of $\mathrm{M} 2$ in the preceding year. This measures the financial deepening of the economy.

The present study identified the gap that most of the studies examine the relationship and impact of the banking and insurance performance on the economic growth of economies. Having identified the gap the present study examines the relationship of the economic growth on the banking and insurance trade performance. Most of the studies are on developed countries, as India is a developing country located in Asia, the present study considers select Asian countries of the low and middle income group.

In the present study economic growth is considered as dependent variable and it is represented by three variables. They are DOMCREDIT, GDPP and M2GDP and the banking and insurance performance as represented by BIPER is considered as the independent variable.

In the present study, eight countries of Asian region - covering both Low and Middle group (also based on the availability of data) are chosen. They are Indonesia, India, Sri Lanka, Maldives, Malaysia, Pakistan, Philippines and Thailand. Therefore, time series of eight countries for a period from 2005-06 to 2012-13 is considered for four variables. The time period for the study is from 2005 to 2012. The following variables are considered for the study:

1. BIPER - Banking and Insurance percentage of Service Exports

2. Dom Credit to GDP - Domestic Credit provided by financial sector as a percentage of GDP

3. GDPP-GDP percapita

4. M2 to GDP - Money and Quasi Money as a percentage of GDP - financial deepening

\section{Equations}

$\mathrm{BIPER}=\mathrm{f}(\mathrm{GDPP}$ M2GDP DOMCREDIT $)$

The research model can be written as

BIPER $=\alpha+\beta$ GDPP $+\gamma$ M2GDPP $+\delta$ DOMCREDIT $+u_{t}$

$\alpha, \beta, \gamma, \delta=$ parameters to be estimated

$\operatorname{BIPER}_{\mathrm{it}}=\alpha_{1}+\beta_{1}\left(\mathrm{GDPP}_{\mathrm{it}}\right)+\beta_{2}\left(\mathrm{D}_{1} *\left(\mathrm{GDPP}_{\mathrm{it}}\right)\right)+\beta_{3}\left(\mathrm{D}_{2} *\left(\mathrm{GDPP}_{\mathrm{it}}\right)\right)+\beta_{4}\left(\mathrm{D}_{3} *\left(\mathrm{GDPP}_{\mathrm{it}}\right)\right)+$

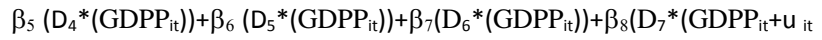

$\mathrm{BIPER}_{\mathrm{it}=} \alpha_{2}+\beta_{11}\left(\mathrm{M} 2 \mathrm{GDP}_{\mathrm{it}}\right)+\beta_{12}\left(\mathrm{D}_{1} *\left(\mathrm{M}_{2} \mathrm{GDP}_{\mathrm{it}}\right)\right)+\beta_{13}\left(\mathrm{D}_{2} *\left(\mathrm{M} 2 \mathrm{GDP}_{\mathrm{it}}\right)+\beta_{14}\left(\mathrm{D}_{3} * \mathrm{M} 2 \mathrm{GDP}_{\mathrm{it}}\right)+\beta_{15}\left(\mathrm{D}_{4} *(\mathrm{M} 2 \mathrm{GD}\right.\right.$

$\left.\left.\mathrm{P}_{\mathrm{it}}\right)+\beta_{16}\left(\mathrm{D}_{5} *\left(\mathrm{M}_{2} \mathrm{GDP}_{\mathrm{it}}\right)\right)+\beta_{17}\left(\mathrm{D}_{6} *\left(\mathrm{M}_{2} \mathrm{GDP}_{\mathrm{it}}\right)\right)+\beta_{18}\left(\mathrm{D}_{7} * \mathrm{M} 2 \mathrm{GDP}_{\mathrm{it}}\right)\right)+\mathrm{u}_{\mathrm{it}}$

BIPER $_{\text {itt }}=\alpha_{3}+\beta_{21}\left(\right.$ DOMCREDIT $\left._{i t}\right)+\beta_{22}\left(D_{1} *\left(\right.\right.$ DOMCREDIT $\left.\left._{i t}\right)\right)+\beta_{23}\left(D_{2} *\left(\right.\right.$ DOMCREDIT $\left.\left._{\mathrm{it}}\right)\right)+\beta_{24}\left(\mathrm{D}_{3} *(\right.$ DOMCRE $\left.\operatorname{DIT}_{\text {it }}\right)+\beta_{25}\left(\mathrm{D}_{4} *\left(\right.\right.$ DOMCREDIT $\left.\left._{\text {it }}\right)\right)+\beta_{26}\left(\mathrm{D}_{5} *\left(\right.\right.$ DOMCREDIT $\left.\left._{\text {it }}\right)\right)+\beta_{27}\left(\mathrm{D}_{6} *\left(\right.\right.$ DOMCREDIT $\left.\left._{\text {it }}\right)\right)+\beta_{28}\left(\mathrm{D}_{7} *\left(\right.\right.$ DOMCREDIT $\left.\left._{\text {it }}\right)\right)$ $++\mathrm{u}_{\text {it }}$

Where

$\mathrm{i}=$ cross-section-data (the choosen country)

$\mathrm{t}=$ time series data

BIPER $_{\mathrm{it}=}$ Banking and insurance share as percentage of total services of country $\mathrm{i}$ at time $\mathrm{t}$; 
GDPP $_{\text {it }}=$ Gross domestic Product Per capita of country $\mathrm{i}$ at time $\mathrm{t}$;

$\mathrm{M}_{2 \mathrm{GDP}}$ it $=$ Ratio of M2 to Gross Domestic Product of country i at time t;

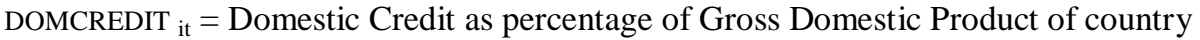
$\mathrm{i}$ at time $\mathrm{t}$;

$\mathrm{u}_{\text {it }}=$ independently distributed random error term, with zero mean and constant variance number $i$ at time $t$;

$\mathrm{D}_{1}=1$ is India, $\mathrm{D}_{1}=0$ is otherwise

$\mathrm{D}_{2} \quad=1$ is Indonesia, $\mathrm{D}_{2}=0$ is otherwise

$\mathrm{D}_{3}=1$ is Malaysia, $\mathrm{D}_{3}=0$ is otherwise

$\mathrm{D}_{4}=1$ is Maldives, $\mathrm{D}_{4}=0$ is otherwise

$\mathrm{D}_{5}=1$ is Pakistan, $\mathrm{D}_{5}=0$ is otherwise

$\mathrm{D}_{6}=1$ is Philippines, $\mathrm{D}_{6}=0$ is otherwise

$\mathrm{D}_{7} \quad=1$ is Srilanka, $\mathrm{D}_{7}=0$ is otherwise

\section{Results}

There is a lot of literature on the impact of banking and insurance trade performance on the economic growth of an economy. The present study examines the gap and studies the impact of economic growth on the banking and insurance trade performance. The study also considers the low and middle income countries of Asia. The reason for conducting the study on the Low and Middle Income group is that most of the studies in this area are done on developed economies and hence the study considers low and middle income countries, also identifying that no study is done with South Asian countries in this aspect.

The study examines the relationship between the independent variable BIPER and the dependent variables DOMCREDIT, GDPP and M2GDP by conducting one to one using Pedroni Residual Cointegration Test. Table 2 below shows the results of the Pedroni Residual Cointegration conducted for the variables BIPER and DOMCREDIT. Table 3 shows that there is a positive relationship among the variables BIPER and DOMCREDIT. Since in majority of tests $p$ value is less than alpha (0.05) null hypothesis (series is not cointegrated) is rejected. As null hypothesis is rejected alternative hypothesis is accepted and it can be concluded that series BIPER and the series DOMCREDIT are co integrated.

Table 2 Panel Cointegration Results between BIPER and DOMCREDIT

\begin{tabular}{|l|c|c|c|c|}
\hline & Statistic & Probability & Weighted Statistic & Probability \\
\hline Panel v-Statistic & 1.747726 & 0.0403 & -0.49014 & 0.688 \\
\hline Panel rho-Statistic & -1.85058 & 0.0321 & -0.76459 & 0.2223 \\
\hline Panel PP-Statistic & -5.38524 & 0 & -3.8641 & 0.0001 \\
\hline Panel ADF-Statistic & -5.28529 & 0 & -3.70654 & 0.0001 \\
\hline & Statistic & Probability & & \\
\hline Group rho-Statistic & 0.306304 & 0.6203 & & \\
\hline Group PP-Statistic & -3.85954 & 0.0001 & & \\
\hline Group ADF-Statistic & -4.035 & 0 & & \\
\hline
\end{tabular}


Table 3 Cross Section Specific Results - BIPER and DOMCREDIT

\begin{tabular}{|l|c|c|c|c|}
\hline \multicolumn{5}{|c|}{ Phillips-Peron Results (Non-Parametric) } \\
\hline Cross ID & Variance & HAC & Bandwidth & Observations \\
\hline India & 0.273171 & 0.172637 & 6 & 7 \\
\hline Indonesia & 0.250836 & 0.209568 & 2 & 7 \\
\hline Malaysia & 0.031005 & 0.024575 & 2 & 7 \\
\hline Maldives & 0.021406 & 0.007401 & 6 & 7 \\
\hline Pakistan & 0.398884 & 0.460992 & 1 & 7 \\
\hline Philippines & 0.045951 & 0.035193 & 3 & 7 \\
\hline Sri Lanka & 0.077753 & 0.094074 & 1 & 7 \\
\hline Thailand & 0.022552 & 0.022552 & 0 & 7 \\
\hline \multicolumn{2}{|c|}{ Augmented Dickey-Fuller Results (Parametric) } \\
\hline Cross ID & Variance & Lag & Max lag & Observations \\
\hline India & 0.273171 & 0 & 0 & 7 \\
\hline Indonesia & 0.250836 & 0 & 0 & 7 \\
\hline Malaysia & 0.031005 & 0 & 0 & 7 \\
\hline Maldives & 0.021406 & 0 & 0 & 7 \\
\hline Pakistan & 0.398884 & 0 & 0 & 7 \\
\hline Philippines & 0.045951 & 0 & 0 & 7 \\
\hline Sri Lanka & 0.077753 & 0 & 0 & 7 \\
\hline Thailand & 0.022552 & 0 & 0 & 7 \\
\hline
\end{tabular}

The relationship between independent variable BIPER and the dependent variable GDPP is checked for using the Pedroni Co-integration. Table 4 shows that the null hypothesis is rejected showing that there is a positive relationship among the variables BIPER and GDPP. Since in majority of tests $p$ value is less than alpha (0.05) null hypothesis (series is not cointegrated) is rejected. As null hypothesis is rejected alternative hypothesis is accepted and it can be concluded that series BIPER and GDPP are co integrated. Table 6 shows the Pedroni Panel Cointegration results for verifying the relationship using variables BIPER and M2GDP. Since in majority of tests $p$ value is less than alpha (0.05) null hypothesis (series is not cointegrated) is rejected. As null hypothesis is rejected alternative hypothesis is accepted and it can be concluded that series BIPER and M2GDP is cointegrated.

Table 4 Panel Cointegration Results for Variables BIPER and GDPP

\begin{tabular}{|l|c|c|c|c|}
\hline & Statistic & Probability & Statistic & Probability \\
\hline Panel v-Statistic & 1.873808 & 0.0305 & 0.54905 & 0.2915 \\
\hline Panel rho-Statistic & -2.19173 & 0.0142 & -1.19623 & 0.1158 \\
\hline Panel PP-Statistic & -5.52701 & 0 & -3.91482 & 0 \\
\hline Panel ADF-Statistic & -5.47001 & 0 & -3.87328 & 0.0001 \\
\hline & Statistic & Probability & & \\
\hline & 0.173041 & 0.5687 & & \\
\hline Group rho-Statistic & -5.01776 & 0 & & \\
\hline Group PP-Statistic & -3.75355 & 0.0001 & & \\
\hline Group ADF-Statistic & & & & \\
\hline
\end{tabular}


Table 5 Cross Section Specific Results - BIPER and GDPP

\begin{tabular}{|c|c|c|c|c|}
\hline Cross ID & Variance & HAC & Bandwidth & Observations \\
\hline India & 0.200547 & 0.224873 & 1 & 7 \\
\hline Indonesia & 0.130221 & 0.027666 & 6 & 7 \\
\hline Malaysia & 0.032602 & 0.029852 & 1 & 7 \\
\hline Maldives & 0.022998 & 0.013084 & 4 & 7 \\
\hline Pakistan & 0.460615 & 0.460615 & 0 & 7 \\
\hline Philippines & 0.040231 & 0.027968 & 3 & 7 \\
\hline Sri Lanka & 0.121755 & 0.164479 & 1 & 7 \\
\hline Thailand & 0.030334 & 0.034632 & 1 & 7 \\
\hline Cross ID & Lag & Max lag & Obs & \\
\hline India & 0 & 0 & 7 & \\
\hline Indonesia & 0 & 0 & 7 & \\
\hline Malaysia & 0 & 0 & 7 & \\
\hline Maldives & 0 & 0 & 7 & \\
\hline Pakistan & 0 & 0 & 7 & \\
\hline Philippines & 0 & 0 & 7 & \\
\hline Sri Lanka & 0 & 0 & 7 & \\
\hline Thailand & 0 & 0 & 7 & \\
\hline
\end{tabular}

Table 6 Panel Cointegration Results for BIPER and M2GDP

\begin{tabular}{|l|c|c|c|}
\hline & Statistic & Probability & Statistic \\
\hline Panel v-Statistic & 1.677109 & 0.0468 & -0.25232 \\
\hline Panel rho-Statistic & -1.77301 & 0.0381 & -0.63403 \\
\hline Panel PP-Statistic & -4.39433 & 0 & -4.58718 \\
\hline Panel ADF-Statistic & -4.35997 & 0 & -4.04933 \\
\hline & Statistic & Probability & \\
\hline Group rho-Statistic & 0.417868 & 0.662 & \\
\hline Group PP-Statistic & -5.32673 & 0 & \\
\hline
\end{tabular}

Table 7 Cross Section Specific Results of BIPER and M2GDP

\begin{tabular}{|l|c|c|c|c|}
\hline \multicolumn{1}{|c|}{ Cross ID } & AR1 & Variance & Observations \\
\hline India & -0.189 & 0.217638 & 6 & 7 \\
\hline Indonesia & -0.57 & 0.208958 & 2 & 7 \\
\hline Malaysia & -0.173 & 0.026149 & 3 & 7 \\
\hline Maldives & -0.134 & 0.015077 & 6 & 7 \\
\hline Pakistan & -0.51 & 0.505835 & 1 & 7 \\
\hline Philippines & -0.167 & 0.046812 & 3 & 7 \\
\hline Sri Lanka & 0.142 & 0.199607 & 2 & 7 \\
\hline Thailand & -0.536 & 0.019042 & 6 & 7 \\
\hline Augmented Dickey Fuller Test & & & & \\
\hline
\end{tabular}


The present study examined the relationship between economic growth and banking and insurance performance. The study is done for select Asian countries for a period of nine years from 2005 to 2013. Most of the literature shows that banking and insurance performance has an impact on the economic growth of the economy. But the present paper examines the relationship between economic growth and banking and insurance performance. When an economy grows it does have an impact on the level of activities, international trade and thus has an impact on banking and insurance trade performance also. To check this relationship banking and insurance performance [BIPER] has been taken as the independent variable and three variables [GDPP, M2GDP, DOMCREDIT] representing economic growth have been taken as dependent variables.

The Pedroni co-integration test (Panel Co-integration) test when performed shows that there is significant relationship between Banking and Insurance performance and the variables like Domestic Credit provided by financial sector, Money and Quasi money and GDP. Thus, it shows the relationship between economic growth and banking and insurance performance of an economy. Which shows that as the economy grows the banking and insurance trade performance also grows.

The second part of the analysis is to check for which countries there is a strong relationship between the dependent and independent variables. Taking India as the reference country the relationship of the variables in India is examined and it is also if the relationship shows a similar pattern in other countries.

Pedroni Panel co-integration tests are carried out on independent and dependent variables. It has been found and concluded that the independent variable Banking and Insurance trade performance [BIPER] and the dependent variables [DOMCREDIT], BIPER and M2GDP, BIPER and series are cointegrated. They all move in the same direction. They show that the growth and development of the country has impact on the banking and insurance performance.

The relationship between the independent variable BIPER and the dependent variable representing economic growth DOMCREDIT is examined with panel cointegration and it is found that there is a strong relationship between the two. Similarly the relationship between BIPER and the M2b to GDP has been examined and found that there is also a strong relationship between the variables. The relationship between BIPER and GDPP (another variable representing the Economic Growth) is also being checked for and it is found that there is a strong relationship between all the three variables of Economic Growth and the Banking and Insurance Performance.

The study also checks if the relationship of economic growth and banking and insurance performance in each country is the same as in the case of the reference country. In the present study India is taken as the reference country. As a first step WALD test is conducted to understand whether fixed effects model or OLS test should be conducted.

From the above Table since the value of $\mathrm{p}$ is less than alpha. It indicates that Fixed effect model is better than Pooled OLS model.

$\mathrm{BIPER}=\mathrm{C}(1)+\mathrm{C}(2) * \mathrm{GDPP}+\mathrm{C}(3) * \mathrm{DOMCREDIT}+\mathrm{C}(4) * \mathrm{M} 2 \mathrm{GDP}+\mathrm{C}(5) * \mathrm{D} 1+\mathrm{C}(6) * \mathrm{D} 2+\mathrm{C}(7) * \mathrm{D} 3+\mathrm{C}(8) * \mathrm{D} 4$ $+\mathrm{C}(9) * \mathrm{D} 5+\mathrm{C}(10) * \mathrm{D} 6+\mathrm{C}(11) * \mathrm{D} 7$

India has been taken as the base country .All other countries have been compared taking Indian values as the reference. Based on the p-values for the dummy 
coefficients, it can be said that only Sri Lanka with a $p$ value $(0.3299)$ which is greater than 0.05 does not have intercepts that differ significantly from Indian intercept of 2.8149. It shows that in SriLanka the relationship of the independent variable BIPER and the dependent variables is not significant and it is also not as it is in the reference country, India.

Using fixed effect dummy variable regression, India was taken as the reference country and the relationship between banking and insurance performance and economic growth as indicated by the variables BIPER, DOMCREDIT, GDPP and M2GDP is checked. The test reveals if the relationship is same as in the reference country. The Fixed effects test reveals that there is significant country effects meaning the relationship in all the countries are in the similar direction as in India except for SriLanka. The results reveal that variables BIPER, DOMCREDIT, GDPP and M2GDP have strong effect in the countries Pakistan, Maldives, Indonesia, Malaysia, Thailand and Philippines.

The coefficients for the countries Pakistan, Maldives, Indonesia, Malaysia, Thailand and Philippines were found to be significant. Only SriLanka doesn't not show significant relationship among the dependent and independent variables. It also does not show a similar trend in the relationship between the variables BIPER, GDPP, DOMCREDIT and M2GDP as shown in India and other Asian countries.

\section{Conclusion}

The present study examined the relationship between economic growth and banking and insurance performance. The study is done for select Asian countries for a period of nine years from 2005 to 2013. Most of the literature shows that banking and insurance performance has an impact on the economic growth of the economy. But we believe and wanted to check the relationship other way round. When an economy grows it does have an impact on the level of activities, international trade and thus has an impact on banking and insurance trade performance also.

Pedroni Panel co-integration tests (as shown from Table 2 to Table 7) are carried out on independent and dependent variables. It has been found and concluded that the independent variable Banking and Insurance trade performance [BIPER] and the dependent variables [DOMCREDIT], BIPER and M2GDP, BIPER and GDPP series are cointegrated. They all move in the same direction. They show that the growth and development of the country has impact on the banking and insurance performance. Thus the analysis helps us to conclude that there is a significant relationship as shown by the Pedroni Panel Co-integration Test.

The analysis done by using Fixed effects model for the eight Asian countries shows that in Sri Lanka the relationship of the independent variable BIPER and the dependent variables is not significant and it is also not as it is in the reference country, India. All the other countries except Sri Lanka show significant relationship among the dependent and independent variables and also show a similar trend between the variables as is visible from the results of fixed effects - a panel regression test.

It is concluded that there is a good theoretical point for the economic growth influencing banking and insurance performance (and vice versa), but only weak empirical evidence as of now. The empirical findings of the present paper point to future possibilities in investigating the nexus further by using different indicators for the banking and insurance performance. The results indicate that the economic 
growth of an economy also impacts or influences the banking and insurance performance in a country.

With the lessons learnt from the crisis, many countries have been reviewing their banking structures post crisis. It is important to review the banking structure in the Indian context also with a view to enabling the banking sector to cater to the needs of a growing and globalizing economy as well as furthering financial inclusion.

Another useful extension of this study would be to include the equity markets into the model. Although the equity and debt markets in developing economies are far from developed and their role in financing being limited, it would be interesting to examine their role in economic development.

\section{References}

1. Adams, M., J. Andersson, L. F. Andersson, and M. Lindmark, 2005, The Historical Relation between Banking, Insurance and Economic Growth in Sweden: 1830 to 1998,Working Paper SBE 2006/2, University of Wales Swansea

2. Aliber, Robert Z. 1976,"Towards a theory of international banking. Federal Reserve Bank of San Fransisco", Economic Review Spring, 5-8.

3. Arena, M., 2008, Does Insurance Market Activity Promote Economic Growth? A Cross-Country Study for Industrialized and Developing Countries, Journal of Risk \& Insurance, 75(4): 921-946.

4. Bencivenga, V. R. \& Smith, B. 1991. Financial intermediation and endogenous growth. Review of Economic Studies 58, 195-209.

5. Berg, A., Borensztein, E., Sahay, R. \& Zettelmeyer, J. 1999. The evolution of output in transition economies: explaining the differences. IMF Working Paper 99/73.

6. Berglöf, E. \& Bolton, P. 2002. The great divide and beyond - Financial architecture in transition. Journal of Economic Perspectives 16. 77-100.

7. Blackburn, K. \& Hung, V. T. Y. 1998. A theory of growth, financial development and trade. Economica 65, 107-124.

8. Claessens, Stijn, and Neeltje Van Horen, (2013), "Impact of Foreign Banks," The Journal of Financial Perspectives, Vol. 1, No. 1, 1-14.

9. Contador, C.R. and Ferraz, C. B. 2007. Insurance and Economic Growth: Some International Evidences. RBRSi, Rio de Janeiro, Brazil, 1:1, 41-78

10. De Melo, M., Denizer, C. \& Gelb, A. 1996. From plan to market: patterns of transition. World Bank Policy Research Working Paper 1564.

11. Demetriades, P. \& Hussein, K. A. 1996. Does financial development cause economic growth. Journal of Development Economics 51, 387-411.

12. Drakos, K. 2002. Imperfect competition in banking and macroeconomic performance: Evidence from the transition economies. European Bank for Reconstruction and Development. Transition Report. European Bank for Reconstruction and Development, London, various issues.

13. Goldsmith, R. 1969. Financial structure and development. New Haven. Yale University Press.

14. Greenwood, J. \& Jovanovic, B. 1990. Financial development, growth and the distribution of income. Journal of Political Economy 98, 1076-1107. 
15. Haiss, P., and K. Sümegi, 2008, the Relationship of Insurance and Economic Growth in Europe: A Theoretical and Empirical Analysis, Emprica, 35(4): 405431.

16. Khan, S. M. and Senhadji, S. (2002), Financial Development and Economic Growth: An Overview, International Monetary Fund.

17. King, R. and Levine, R. (1993a) Finance and Growth: Schumpeter Might Be Right, Quarterly Journal of Economics 108: 717-37.

18. Koetter, M. and M. Wedow (2006). Is it quantity or quality that matters? Finance and growth in a bank based economy. Bundes bank Discussion Paper Series 2, 2.

19. Thorgeirsson, T. 2001. Contributions of financial systems to growth in OECD countries. OECD Economic Department Working Paper No. 280.

20. Levine, R. 1991. Stock markets, growth and tax policy. The Journal of Finance 46, 1445- 1465.

21. Levine, R. 1997. Financial development and economic growth: Views and agenda. Journal of Economic Litterature 35, 688-726.

22. Levine, R., Loayza, N. \& Beck, T. 2000. Financial intermediation and growth: Causality and causes. Journal of Monetary Economics 46, 31-77.

23. Levine, R. \& Zervos, S. 1996. Stock market development and long-run growth. World Bank Economic Review 10, 323-339.

24. Levine, R. \& Zervos, S. 1998. Stock markets, banks and economic growth. American Economic Review 88, 537-558.

25. Mitchell, J. 2001. Banks' bad debts: Policies, creditor passivity, and soft budget constraints. In Designing financial systems in transition economies. Edited by Meyendorff, A. and Thakor, A. V. The Williams Davidson Institute. The MIT Press. London, England.

26. Neusser, K. \& Kugler, M. 1998. Manufacturing growth and financial development: Evidence from OECD countries. Review of economics and statistics 80, 638-646.

27. Pagano, M. 1993. Financial markets and growth: An overview. European Economic Review 37, 613-622.

28. Quah, D. 1993. Empirical cross-section dynamics in economic growth. European Economic Review 37, 426-434.

29. Rajan, R. G. \& Zingales, L. 1998. Financial dependence and growth. American Economic Review 88, 559-586.

30. Rousseau, P. L. \& Wachtel, P. 1998. Financial intermediation and economic performance: historical evidence from five industrial countries. Journal of Money, Credit and Banking 30, 657-678.

31. Rousseau, P. L. \& Wachtel, P. 2000. Equity markets and growth: Cross-country evidence on timing and outcomes, 1980-1995. Journal of Banking and Finance 24, 133-57.

32. Rousseau, P. L. \& Wachtel, P. 2002. Inflation threshold and the finance-growth nexus. Journal of international money and finance.

33. Levine, Ross. 1991 Stock markets, growth, and tax policy. Journal of Finance, 1445-1465.

34. Levine, R. (1997). Financial development and economic growth: Views and agenda. Journal of Economic Literature 2, 688-7266. 
35. Levine, R., N. Loayza, and T. Beck (2000). Financial intermediation and growth: Causality and causes. Journal of Monetary Economics 46, 31-77.

36. Levine, R. and S. Zervos (1998): Stock Markets, Banks and Economic Growth, American Economic Review 88, pages 537-58.

37. Maldonado, R.M., 1970, the Role of the Financial Sector in the Economic Development of Puerto Rico, Washington, D.C.: Federal Deposit Insurance Corporation.

38. McCauley, R., \& Zukunft, J. (2008).Asian banks and the international interbank market. BIS Quarterly Review, 67-79.

39. Odedokun, M.O., 1991, Differential impacts of export expansion on economic growth in LDCs: A comparison of evidences across regional income groups and between the decades of 1970s and 1980s, Eastern Africa Economic Review, 7.

40. Odedokun, M.O., 1996, Alternative econometric approaches for analyzing the role of the financial sector in economic growth: Time-series evidence from LDCs, Journal of Development Economics, Vol. 50.

41. Patrick, H.T., 1966, Financial development and economic growth in underdeveloped countries, Economic Development and Cultural Change, Jan

42. Ram, R., 1999, Financial Development and Economic Growth: Additional Evidence, Journal of Development Studies, 35(4), pages164-174.

Rousseau L Peter and Paul Wachtel.'Inflation thresholds and finance-growth nexus" Journal of International Money and Finance, November 2002, pp. 77793.

43. Roubini, N. and X. Sala-i-Martin, 1992. "Financial Repression and Economic Growth", Journal of Development Economics, 39 (1), pp. 5-30.

44. Schumpeter, J. A. 1934. The theory of economic development. Cambridge, MA. Harvard University Press.

45. Seema Joshi (2008), Growth and Structure of Tertiary Sector in Developing Economies", Academic Foundation, Delhi, 2008.

46. Seth, R., Nolle, D.E., Mohanty, S.K., 1998. Do banks follow their customers abroad? Financial Markets, Institutions and Instruments 7(4), 1-25

47. Sherman, H.David, and Franklin gold, "Bank Branch Operating Efficiency: Evaluation with Data Envelopment analysis," Journal of Banking and Finance (June 1985). Pp. 297 -315

48. Siriopoulos, C., Tziogkidis, P. (2009). How do Greek banking institutions react after significant events? - A DEA Approach (forthcoming in Omega).

49. Sümegi, K., and P. Haiss, 2008, The Relationship between Insurance and Economic Growth: Review and Agenda. The Icfai Journal of Risk and Insurance, 1 (2): 32-56.

50. Tang, H., Zoli, E. and Klytchnikova, I. 2000. Banking crises in transition countries: Fiscal costs and related issues. World Bank Policy Research Working Paper 2484.

51. Thiel, M. 2001. Finance and economic growth - A review of theory and the available evidence. European Commission. Brussels.

52. Tsuru, K. 2000. Finance and growth. OECD Economics Department Working Paper 228. OECD, Paris.

53. Ward, D., and R. Zurbruegg, 2000, Does Insurance Promote Economic Growth? Evidence from OECD Countries, The Journal of Risk and Insurance, 67(4), pages 489-506. 
54. Wadlamannati, K.C., 2008. "Do Insurance Sector Growth \& Reforms Effect Economic Development? - Empirical Evidence from India", The Journal of Applied Economic Research, 2(1), pp. 43-86.

55. Wachtel, P. 2001. Growth and finance - What do we know and how do we know it? International Finance 4, 335-362.

56. Webb, I., M.F. Grace, and H. Skipper, 2005. "The effect of banking and insurance on the growth of capital and output", SBS Revista de Temas Financieros (Journal of Financial Issues) 2(2), pp. 1-32.

57. Williams, B., (1997)," Positive theories of multinational banking: eclectic theory versus internalization theory". Journal of Economic Surveys 11(1), pages 71100.

\section{Annexures}

Table 8 Wald Test Coefficients

\begin{tabular}{|l|c|c|c|}
\hline \multicolumn{1}{|c|}{ Test Statistic } & Value & DF & Probability \\
\hline F-statistic & 61.52575 & $(7,53)$ & 0 \\
\hline Chi-square & 430.6802 & 7 & 0 \\
\hline Null Hypothesis Summary: & & & \\
\hline Normalized Restriction (=0) & & Value & Std. Err. \\
\hline C(5) & & 3.797988 & 0.343074 \\
\hline C(6) & & 3.197606 & 0.468279 \\
\hline $\mathrm{C}(7)$ & & 1.919094 & 0.417819 \\
\hline $\mathrm{C}(8)$ & & -0.35315 & 0.49819 \\
\hline $\mathrm{C}(9)$ & & 1.729015 & 0.420529 \\
\hline $\mathrm{C}(10)$ & & -1.24549 & 1.041886 \\
\hline $\mathrm{C}(11)$ & -2.38287 & 0.796307 \\
\hline
\end{tabular}

Table 9 Cross Section Data Analysis - Fixed Effects

\begin{tabular}{|c|c|c|c|c|}
\hline Country code & Coefficient & Std. Error & t-Statistic & Prob. \\
\hline $\mathrm{C}(1)$ & 2.814913 & 1.053349 & 2.672345 & 0.01 \\
\hline$C(2)$ & -0.00015 & $9.45 \mathrm{E}-05$ & -1.60186 & 0.1151 \\
\hline $\mathrm{C}(3)$ & 0.008299 & 0.012936 & 0.641531 & 0.5239 \\
\hline $\mathrm{C}(4)$ & 0.031122 & 0.020763 & 1.498918 & 0.1398 \\
\hline $\mathrm{C}(5)$ & -0.60038 & \begin{tabular}{|l|}
0.610493 \\
\end{tabular} & \begin{tabular}{|l|}
-0.98344 \\
\end{tabular} & 0.3299 \\
\hline$C(6)$ & -1.8789 & 0.524386 & -3.58304 & 0.0007 \\
\hline $\mathrm{C}(7)$ & -4.15114 & 0.617941 & -6.7177 & 0 \\
\hline $\mathrm{C}(8)$ & -2.06897 & 0.584555 & -3.5394 & 0.0008 \\
\hline $\mathrm{C}(9)$ & -5.04348 & 0.951621 & 988 & 0 \\
\hline $\mathrm{C}(10)$ & 86 & 0.609165 & -10.1464 & 0 \\
\hline $\mathrm{C}(11)$ & -3.79799 & 0.343074 & \begin{tabular}{|l|}
-11.0705 \\
\end{tabular} & 0 \\
\hline R-sq & & \multicolumn{2}{|c|}{ Mean dependent var } & 2.122964 \\
\hline Adjusted R-squared & 0.910908 & \multicolumn{2}{|c|}{ S.D. dependent var } & 1.683897 \\
\hline S.E. of regression & 0.502616 & \multicolumn{2}{|c|}{ Akaike info criterion } & 1.617177 \\
\hline Sum squared resid & 13.38899 & \multicolumn{2}{|c|}{ Schwarz criterion } & 1.988235 \\
\hline Log likelihood & -40.7497 & \multicolumn{2}{|c|}{ Hannan-Quinn criter. } & 1.763355 \\
\hline F-statistic & 65.41307 & \multirow{2}{*}{\multicolumn{2}{|c|}{ Durbin-Watson stat }} & 2.10744 \\
\hline Prob (F-statistic) & 0 & & & \\
\hline
\end{tabular}


About Our Authors

Srijanani Devarakonda has more than 20 years of teaching experience and 2 years of industry experience. She has attended 16 national and international conferences and published 12papers in journals of repute. She is the assistant editor of Gavesana - Journal of Management, VJIM. She did her PhD from Osmania University. She is presently working as an Associate Professor in the area of accounting and finance at VignanaJyothi Institute of Management, Hyderabad. She can be reached at jananio4@yahoo.com

Usha Munipalle is a Professor in Department of Commerce, Osmania University. She has over 30 years of experience in teaching. She is has published over 25 in various national and international journals. Her areas of interest include Industrial Economics, Marketing, Business Policy and Environment, Taxation. Cost Accounting, International business. She is guiding around $6 \mathrm{PhD}$ scholars. She also worked on a UGC project "The Impact Of Tax Reforms On Federal Revenues Of India". She is presently working on a book "Managerial Economics and Financial Accounting" for Engineering students. She is a very popular faculty and a good researcher. She can be reached at muni_21@rediffmail.com 